\title{
New reports of helminthes in captive exotic psittacine birds in Chile
}

\author{
Nuevos antecedentes de helmintos en aves psitácidas exóticas cautivas en Chile \\ G González-Hein $^{\mathrm{a}}$, F Fredes ${ }^{\mathrm{b}}$, M Kinsella ${ }^{\mathrm{c}}, \mathrm{J}_{\text {Larenas }}^{\mathrm{d}}$, D González-Acuña ${ }^{\mathrm{e}}$

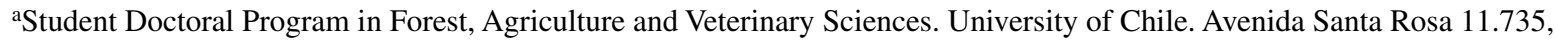 \\ La Pintana, Santiago, Chile. \\ ${ }^{b}$ Laboratory of Parasitology, Department of Animal Preventive Medicine, College of Veterinary Sciences University of Chile, \\ Santiago, Chile.

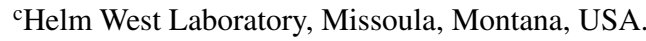 \\ ${ }^{\mathrm{d}}$ Department of Animal Pathology. College of Veterinary Sciences. University of Chile, Santiago, Chile. \\ eDepartment of Animal Sciences, University of Concepción, Chillán, Chile.
}

\begin{abstract}
RESUMEN
A pesar de su importancia, la fauna helmíntica de aves psitácidas ha sido poco investigada en Chile. En el presente estudio se reporta la presencia de Tetrameres sp. en Cyanoramphus novaezelandiae, de Schistorophus sp. en Platycercus flaveolus y de Dispharynx nasuta en P. flaveolus, Platycercus eximius, Platycercus elegans, Polytelis alexandrae, y C. novaezelandiae en diferentes aviarios de la Región Metropolitana de Chile. Los primeros casos de Ascaridia platyceri en P. eximius y C. novaezelandiae son también descritos. Ascaridia platyceri y D. nasuta fueron implicados como la causa de enfermedades serias y fatales en estas aves psitácidas exóticas, mientras que Schistorophus sp. y Tetrameres sp. fueron clínicamente menos significativos.

Key words: helminthes, psittacine, birds, parasites.

Palabras clave: helmintos, psitácidas, aves, parásitos.
\end{abstract}

\section{INTRODUCTION}

Parakeets and parrots from Australia, Africa, Asia and the Pacific region are currently gaining in popularity as pets due to their bright plumage, small to medium size, and ease of breeding in captivity (Levine 2003). The importance of psittacine birds and the fact that they are easily domesticated (Pinto et al 1993) emphasize the need to identify their parasites and generate data on potential pathogens. Often, the only means of obtaining such data is mortality in captive birds (Matos and Morrisey 2005).

Among the species of clinically significant helminthes that occur in psittacine birds are liver flukes, and intestinal nematodes such as Ascarops sp., Ascaridia spp., and Capillaria spp. (Sood and Kalia 1975, Webster and Speckmann 1977, Greiner and Ritchie 1999). However, visceral or aberrant hepatic migration by larval ascarids has also been reported in parrots with severe ascariasis ${ }^{1}$ (Reece et al 1992). Other nematode genera found in the proventriculus and ventriculus are Tetrameres, Dispharynx, Spiroptera, and Procyrnea (Clark 1978, Clark et al 1979,

Accepted: 02.06.2011.

* Avenida Santa Rosa 11.735, La Pintana. Santiago, Chile; ffredes@uchile.cl

1 Charles WB, KS Latimer, EW Howerth, GH Wilson. 1998. Aberrant hepatic ascarid migration in a blue fronted Amazon parrot (Amazona aestiva). http://www.vet.uga.edu/vpp/ivcvm/1998/brockus/index. php, accessed November 1, 2008.
Greiner and Ritchie 1999). Nematode parasites can also be seen on the surface of the eye (Anderson and Diaz-Ungria 1959, Greiner and Ritchie 1999), and in the subcutaneous region, air sacs, and body cavity (Greiner and Ritchie 1999).

Ascarids are the most common parasites found in birds that are maintained in enclosures with access to the ground, and infections are particularly common in budgerigars and cockatiels, while proventricular parasitism by Dispharynx spp. is a common finding in Australian parakeets (Levine 2003). The helminth fauna of psittacine birds has been poorly investigated in Chile, where the population of captive psittacine birds consists of 4 species of native psittacine birds and exotic parrots. There is only a single report on the presence of helminthes (Ascaridia hermafrodita) in two captive female specimens of the slender-billed parakeet (Enicognathus leptorhynchus), found dead at the National Zoo of Santiago, Chile (Gonzalez-Acuña et al 2007). The purpose of the study is to report new helminthes in exotic captive psittacine birds in Chile and supplement existing reports of endohelminthes from America.

\section{MATERIAL AND METHODS}

Helminthes were collected from 11 out of 30 (36.7\%) captive psittacine birds which died between 2003 and 2008 in the Metropolitan Region of Chile. The following parrots species were investigated: 2 Cyanoramphus novaezelandiae, 1 Platycercus flaveolus, 7 Platycercus 
eximius, 3 Platycercus elegans, 3 Polytelis alexandrae, 2 Psittacula krameri,1 Pionus menstruus, 3 Neophema bourkii, 4 Agapornis roseicollis, 1 Agapornis fischeri, 3 Agapornis personatus (table 1). The parasites were collected from birds from four outdoor private collection sites: a 2 year old female Eastern rosella ( $P$. eximius) and a male Yellow rosella ( $P$. flaveolus) from aviary A with a population of 188 psittacine birds; a 3 year old male $P$. eximius from aviary B with more than 200 psittacine birds; a 3 year

Table 1. Total of species of exotic psittacine birds sampled from 4 private collections in the Metropolitan region, Chile, 2003-2008.

Total de especies muestreadas de aves psitácidas exóticas procedentes de 4 colecciones privadas de la Región Metropolitana, Chile, 2003-2008.

\begin{tabular}{lc}
\hline Species & Total \\
\hline Cyanoramphus novaezelandiae & 2 \\
Platycercus flaveolus & 1 \\
Platycercus eximius & 7 \\
Platycercus elegans & 3 \\
Polytelis alexandrae & 3 \\
Psittacula krameri & 2 \\
Pionus menstruus & 1 \\
Neophema bourkii & 3 \\
Agapornis roseicollis & 4 \\
Agapornis fischeri & 1 \\
Agapornis personatus & 3 \\
\hline
\end{tabular}

old female red-fronted parakeet (C. novaezelandiae) from aviary $\mathrm{C}$ with a population of 50 psittacine birds; and 2 P. eximius, 3 Crimson rosellas (P. elegans) and 2 Princess parrots ( $P$. alexandrae) from aviary $\mathrm{D}$ with a population of 61 psittacine birds. Samples of nematodes recovered from these birds were deposited in the Parasitological collection of the Laboratory of Parasitology, Faculty of Veterinary Sciences, University of Chile, and in the helminthological collection of the University of Concepción, Chile. The number of samples obtained (parasites), according to each host species were: 4 from $P$. eximius, 2 from $P$. flaveolus, 3 from $C$. novaezelandiae, 3 from $P$. elegans, and 2 from $P$. alexandrae (table 2). Some nematodes were preserved in $10 \%$ buffered formalin or $70 \%$ ethyl alcohol (Bolette 1998) and cleared in temporary mounts of creosote or lactophenol for identification as it was used by GonzalezAcuña et al 2007. Nematodes were identified to genus using the CIH Keys to the Nematodes (Chabaud 1975) and species identified through morphometric analysis. The key of Kajerova et al 2004a was followed for Ascaridia spp.

\section{RESULTS AND DISCUSSION}

Four genera of nematodes, Ascaridia (Ascaridoidea), Dispharynx (Acuaridae), Tetrameres (Tetrameridae), and an unidentified Schistorophus sp. (Schistorophidae) were found in psittacine hosts of three genera: Platycercus, Polytelis, and Cyanoramphus in Chile. Ascaridia platyceri was found in the small intestine of 2 out of 7 P. eximius and 1 out of 2 C. novaezelandiae. Dispharynx nasuta was found

Table 2. Helminth parasites in exotic captive psittacine birds from 4 private collections in the Metropolitan region, Chile, $2003-2008$. Parásitos helmintos en aves psitácidas exóticas en cautiverio procedentes de 4 colecciones privadas de la Región Metropolitana, Chile, 2003-2008

\begin{tabular}{|c|c|c|c|c|c|c|c|}
\hline Host species & Parasite species & $\begin{array}{l}\text { Avian weight } \\
\text { (g) }\end{array}$ & $\begin{array}{l}\text { Normal } \\
\text { weight }{ }^{\mathrm{b}, \mathrm{c}} \\
\text { (g) }\end{array}$ & $\begin{array}{c}\text { Parasite } \\
\text { load approximate }\end{array}$ & Year & Site of infection & Aviary \\
\hline $\begin{array}{l}\text { Cyanoramphus } \\
\text { novaezelandiae }\left(4^{\mathrm{d}}\right)\end{array}$ & $\begin{array}{l}\text { Ascaridia platyceri, } \\
\text { Dispharynx nasuta } \\
\text { Tetrameres sp. }\end{array}$ & 60 & $50-113$ & $\begin{array}{r}2 \\
<10 \\
\text { ND }\end{array}$ & 2004 & $\begin{array}{l}\text { Intestine } \\
\text { Proventriculus } \\
\text { Proventriculus }\end{array}$ & $\mathrm{C}$ \\
\hline Platycercus elegans $\left(5^{\mathrm{d}}\right)$ & Dispharynx nasuta & 99 & $115-170$ & $>10$ & 2007 & Proventriculus & $\mathrm{D}$ \\
\hline Platycercus elegans $\left(7^{\mathrm{d}}\right)$ & Dispharynx nasuta & 100 & $115-170$ & $>10$ & 2008 & Proventriculus & $\mathrm{D}$ \\
\hline Platycercus elegans $\left(8^{\mathrm{d}}\right)$ & Dispharynx nasuta & 103 & $115-170$ & $>10$ & 2008 & Proventriculus & $\mathrm{D}$ \\
\hline Platycercus eximius $\left(1^{\mathrm{d}}\right)$ & Ascaridia platyceri & 90 & $95-120$ & 100 & 2003 & Intestine & A \\
\hline Platycercus eximius $\left(2^{\mathrm{d}}\right)$ & Ascaridia platyceri & 88 & $95-120$ & $>50$ & 2003 & Intestine & B \\
\hline Platycercus eximius $\left(10^{\mathrm{d}}\right)$ & Dispharynx nasuta & 70 & $95-120$ & $>10$ & 2008 & Proventriculus & $\mathrm{D}$ \\
\hline Platycercus eximius $\left(11^{\mathrm{d}}\right)$ & Dispharynx nasuta & 70 & $95-120$ & $>10$ & 2008 & Proventriculus & $\mathrm{D}$ \\
\hline Platycercus flaveolus $\left(3^{\mathrm{d}}\right)$ & $\begin{array}{l}\text { Dispharynx nasuta } \\
\text { Shistorophus sp. }\end{array}$ & $\mathrm{ND}^{\mathrm{a}}$ & $115-170$ & $\begin{array}{l}>10 \\
\text { ND }\end{array}$ & 2003 & $\begin{array}{l}\text { Proventriculus } \\
\text { Proventriculus }\end{array}$ & A \\
\hline Polytelis alexandrae $\left(6^{\mathrm{d}}\right)$ & Dispharynx nasuta & 105 & $90-120$ & $>10$ & 2008 & Proventriculus & $\mathrm{D}$ \\
\hline Polytelis alexandrae $\left(9^{\mathrm{d}}\right)$ & Dispharynx nasuta & $110 \mathrm{~g}$ & $90-120$ & $>10$ & 2008 & Proventriculus & $\mathrm{D}$ \\
\hline
\end{tabular}

ND: Not determined.

http://www.parrots.org/

http://www.environment.gov.au/cgibin/sprat/public/publicspecies.pl?axon_id=758.

animal number. 
in the proventriculus of only one examined $P$. flaveolus specimen, 3 out of 3 P. elegans, 2 out of 7 P. eximius, 2 out of 3 P. alexandrae and 1 out of 2 C. novaezelandiae. Tetrameres sp. occurred in the proventriculus of 1 out of 2 C. novaezelandiae. A few specimens of a species belonging to the subfamily Schistophophinae (Spirurida) were found in the proventriculus of 1 P. flaveolus. Percentage of birds and henhouse infected with parasites are listed in table 3.

Hosts: animal number (a.n.)1.) a 2 year female $P$. eximius from aviary A with about 100 nematodes Ascaridia platyceri, congestion of the intestinal mucous and poor body condition 2/5, (90 g). (a.n.2.) A 3 year old male $P$. eximius from aviary B with heavy intestinal parasitism by Ascaridia platyceri and poor body condition 2/5, (88 g). (a.n.3.) A male $P$. flaveolus from aviary A was found to have thickening of the proventricular mucosa, ulcers, inflammation and nodules with nematodes in the proventriculus ( $D$. nasuta, Schistorophus sp.). However, these lesions were attributed to the action of severe infestations of D. nasuta. (a.n.4.) A 3 year old female C. novaezelandiae from aviary $\mathrm{C}$, with a body condition of $3 / 5,60 \mathrm{~g}$, and a history of acute mortality. This bird developed uric acid deposits in visceral organs such as the pericardium and kidneys. In this case, the causa mortis was visceral gout and the etiology was not defined. Examination of the digestive tract revealed the presence of two ascarids (Ascaridia platyceri) in the small intestine. This bird also had slight thickening of the proventricular mucosa and presence of few filiform and white worms in the proventriculus identified as Tetrameres sp and D. nasuta.

During December 2007 and May 2008, 7 deaths (11.5 $\%$ mortality rate) were observed in a population of 61 psittacine birds of different species (20 Platycercus sp., 2 Polytelis alexandrae, 16 Amazona aestiva, 5 Pionus menstruus, 7 Psephotus haematonotus, 1 Psittacus erithacus, 2 Eclectus roratus, 1 Cyanoramphus auriceps, and 7 Ara sp.). Intensities of infection of $D$. nasuta exceeded 10 worms per bird in: (a.n.5.) a female 4 year old $P$. elegans in poor body condition (2/5) weighed $99 \mathrm{~g}$. Its necropsy revealed abundant ingesta content in esophagus, crop and proventriculus, melena and anemia. Its proventricular mucosa was ulcerated and swollen with nodules. Nematode eggs were not found in fecal flotations from birds in contiguous cages. (a.n.6.) A female $P$. alexandrae with a body condition of $3 / 5$, weighing $105 \mathrm{~g}$, with severe proventricular lesions. (a.n.7.) A male 3 year old $P$. elegans with a body condition of 2/5 (100 g). (a.n.8.) A male 3 year old P. elegans in poor body condition of $2 / 5,(103 \mathrm{~g})$, with presence of congestion in the proventriculus, and granulomatous injuries with great necrotic component associated with presence of fungi microorganisms in lung compatible with aspergillosis, (a.n.9.) a male 6 month old $P$. alexandrae with a body condition of $3 / 5(110 \mathrm{~g})$, (a.n.10.) an adult female $P$. eximius in poor body condition of $2 / 5(70 \mathrm{~g})$, and finally (a.n.11.) an adult male $P$. eximius with a body condition of $2 / 5(70 \mathrm{~g})$. The common gross finding in necropsies of the 5 Platycercus and 2 Polytelis sp. found dead in aviary $\mathrm{D}$ were a great enlargement of the proventriculus, with the lumen of this organ filled with a thick, white and slimy mucous and digested blood. Histological changes in these species including adult $D$. nasuta attached to the mucosa and epithelial cells of the proventriculus, ulcerations, hemorrhage, necrotic foci, inflammation, and congestion in proventriculus and in some cases destruction of the glandular tissue and muscular layers. Microscopic findings also revealed the presence of a perforant ulcer in the proventricular mucosa in one P. alexandrae. Table 2 summarizes all the individuals infected with helminthes.

Ascaridia spp. and D. nasuta caused serious and fatal diseases in the exotic psittacine birds studied. Ascarids are common parasites found in birds that are maintained in aviaries with access to the ground (Greiner and Ritchie 1999). Infections are often asymptomatic, although weight loss and diarrhea may be seen (Wilson et al 1999). Species that infect psittacine birds include A. columbae (Mines and Green 1983), A. galli (shared with gallinaceous birds) and A. platyceri, with records thus far only from the order Psittaciformes. Other psittaciform-specific Ascaridia species are A. sergiomeirai, A. ornata, A. nicobarensis and A. hermafrodita (Kajerova et al 2004a). A. hermafrodita has been reported as one of the most common nematode species to infect psittacine hosts (Pinto et al 1993). In Brazil, it occurs in several psittacine birds (Serra-Freire and Bianchin 1978, Barros et al 2002). Other Ascaridia species have reported (Mines 1979). A. platyceri was described in Germany (Australian zoogeographical region) in captive parrot species as Platycercus spp., Cyanoramphus auriceps, Neopsephotus bourkii, Nymphicus hollandicus, Polytelis authopeplus and Psephotus haematonotus. The same parasite was also detected in Agapornis taranta

Table 3. Percentage of birds and henhouse infected with parasites reported in this study. Metropolitan region, Chile.

Porcentaje de aves y aviarios infectados con parásitos en el presente estudio. Región Metropolitana, Chile.

\begin{tabular}{lcccc}
\hline Parasite genus & Platycercus & Polytelis & Cyanoramphus & Henhouse \\
\hline Dispharynx & $54.5 \%(6 / 11)$ & $66.7 \%(2 / 3)$ & $50 \%(1 / 2)$ & $75 \%(3 / 4)$ \\
Tetrameres & - & - & $50 \%(1 / 2)$ & $25 \%(1 / 4)$ \\
Shitorophus & $9.0 \%(1 / 11)$ & - & - & $25 \%(1 / 4)$ \\
Ascaridia & $18.2 \%(2 / 11)$ & - & $50 \%(1 / 2)$ & $75 \%(3 / 4)$ \\
\hline
\end{tabular}


from the African region and in Enicognathus ferrugineus in the Neotropical region, Germany (Hartwich and Tscherner 1979). Ten species of Australian psittacines have been reported as hosts of this nematode (Mines 1979). In Canada, A. platyceri was found in Melopsittacus undulatus and Nymphicus hollandicus (Webster 1982) and in New Zealand, in Cyanoramphus spp. (Nixton and Weeks 1985) and Agapornis personatus (Weeks 1981). In the Czech Republic, new hosts among Australian parrots kept in captivity were Alisterus scapularis, Barnardius zonarius, Cacatua sp. In addition it was found in Agapornis originating from the Afrotropical zoogeographical region, in Psittacula kramerii from the Afrotropical and Oriental region, as well as in Amazona leucocephala and Aratinga jandaya from the Neotropical region (Kajerova et al 2004a).

The two new cases reported here of A. platyceri in P. eximius are similar to the case report of Ascaridia in a macaw from Brazil infected with nematodes (Barros et al 2002). There are other cases where Ascaridia spp. has also been associated with fatal disease in farm and exotic birds kept in captivity (Schock and Cooper 1978, Melendez and Lindqis 1979, Charles et al 1998, Greiner and Ritchie 1999).

Dispharynx nasuta has been described in numerous avian orders (Charles et al 1998, Zhang et al 2004). The dispharynxiasis cases in Yellow, Crimson, and Eastern rosella, and Princess parrot were similar to the case described in a $P$. alexandrae, where large numbers of $D$. nasuta were firmly attached to the proventricular mucosa, and these proventricular worms may have been sufficient to have caused nutritional compromise, debilitation and subsequent death of this host (Bolette 1998). This parasite has been reported in association with thickening of the proventricular mucosa in Psittaciformes and the proliferative mucosa may prevent the passage of ingesta, resulting in weight loss and chronic vomiting (Greiner and Ritchie 1999). When 10 or more adult worms were present, a proliferation with necrosis and sloughing of mucosal surfaces and multiple proventricular ulcerations were seen in these Australian parakeets.

Tetrameres nestoris in the ducts of the proventricular glands of a parrot causes destruction of secretory cells and thickening and some necrosis of the epithelium (Clark et al 1979). At least 280 worms were recovered from a single Nestor meridionalis, but no history was provided other than the bird was dead (Clark et al 1979, Greiner and Ritchie 1999). Tetrameres americana was reported from the blue and gold macaw (Ara ararauna) in the lumen of the proventriculus as well as fistulated nodules in the proventriculus wall, in Brazil (Silva et al 2005). In the Chilean Cyanoramphus case, the tetramerid nematode infestation was limited.

Members of the subfamily Schistorophinae have been frequently reported in wild birds (Neveu-Lemaire 1938, Courtney and Forrester 1974). To our knowledge
(Hinojosa and Gonzalez-Acuña 2005), this is the first time a Schistorophus species has been reported in Chile. Studies of parasitic species composition and prevalence and intensity of infections in budgerigars, cockatiels, rosellas and parrots have primarily been carried out on fecal samples. Nematodes of the family Ascarididae, Capillaridae and Heterakidae were recorded, with the highest intensity of infection of Ascarididae and Capillaridae found in P. eximius (Balicka-Ramisz et al 2007). These results obtained in the survey of Balicka-Ramisz and coworkers and in the present study show that introduction of parasitological prophylaxis programs are necessary, especially in the larger birds' farming.

Currently, there are few records of the species of nematodes reported in wild birds in Chile. D. nasuta has been found in California quail (Callipepla californica) (Gonzalez-Acuña et al 2000) and Rock pigeon (Columba livia) (Toro et al 1999) with a prevalence of $4 \%$ and $2 \%$ respectively; and Tetrameres spp. has been identified in C. livia in Santiago and Chillán (Toro et al 1999, Gonzalez-Acuña et al 2004). The infection of D. nasuta and Tetrameres spp. in captive psittacine birds could be explained by indirect contact with pigeons and the presence of parasitized isopods.

The occurrence of A. platyceri in captive psittacine birds in Chile and South America is rare because this is generally a parasite of parrots of the Australian region (Kajerova et al 2004 ${ }^{\mathrm{b}}$ ). This nematode species is also found in populations parasitizing both Australian and African parrots kept in captivity in Europe (Kajerova et al $2004^{\mathrm{a}}$ ). It has also been reported in parrots of Neotropical and Afrotropical origin kept in Germany (Hartwich and Tschemer 1979) and in Czech Republic (Kajerova et al $2004^{\text {b) }}$, but in these cases, psittacines of different zoogeographical origins were caged together. In Netherlands, psittacine birds also were infected with A. platyceri (Van den Brand et al 2007). In the Chilean case, it is probable that the parasite was introduced with the psittacine birds' importation from Europe.

However in all the cases described in this report, we cannot exclude the possibility that some psittacine birds came to the aviaries already parasitized.

All the species involved in the survey are exotic to Chile and some of them acquired helminthic infections. The fact that aviary birds from widely varying geographic regions are combined creates a potential opportunity for introducing diseases or rapid death into unnatural hosts (e.g. native populations). Sanitation and movements of flocks must be restricted between populations.

\section{SUMMARY}

In spite of its importance, the helminthic fauna from psittacine birds has been poorly investigated in Chile. The occurrence of Tetrameres sp. is reported in Cyanoramphus novaezelandiae, a Schistorophus sp. in Platycercus flaveolus, and Dispharynx nasuta in P. flaveolus, Platycercus eximius, Platycercus elegans, Polytelis alexandrae, and C. novaezelandiae 
located in different aviaries of the Metropolitan Region of Chile. The first cases of Ascaridia platyceri in P. eximius and C. novaezelandiae are also described. Ascaridia platyceri and D. nasuta were implicated as the cause of serious and fatal disease in these exotic psittacine birds while, other organisms such as the Schistorophus sp. and Tetrameres sp. were clinically less significant.

\section{ACKNOWLEDGEMENTS}

The authors acknowledge the collaboration of Dr. Hector Hidalgo Olate and Dr. Federico Cifuentes (Department of Animal Pathology, College of Veterinary Sciences, University of Chile), in some avian necropsy cases.

\section{REFERENCES}

Anderson RC, C Díaz-Ungria. 1959. Revisión preliminar de las especies de Thelazia Bosc (Spiruroidea: Thelaziidae), parásitas de aves. Mem Soc Cien Nat La Salle 19, 37-75.

Balicka-Ramisz A, A Tomza-Marciniak, B Pilarczyk, M WieczorekDabrowska, M Bkowska. 2007. Intestinal parasites of parrots. Wiad Parazytol 53, 129-132.

Barros LA, LP Fedullo, FM Almeida, RM Pinto. 2002. First case report of Ascaridia hermafrodita (Froelich, 1789) Railliet \& Henry, 1914 (Nematoda Ascaridoidea) in the Brazilian hyacinth macaw, Andorhynchus hyacinthinus (Latham, 1790) Spix, 1824 (Aves Psitacidae). R Bras Ci Vet 9, 114-115.

Bolette DP. 1998. Dispharynxiasis in a captive Princesa Parrot. $J$ Wildl Dis 34, 390-391.

Clark WC. 1978. Procyrnea kea sp. nov. (Procyrnea kea sp. nov. (Habronematidae: Spirurida; Nematoda) from the New Zealand kea (Nestor notabilis Gould 1865) (Aves Psittaciformes). J Roy Soc New Zealand 8, 323-328.

Clark WC, H Black, DM Rudherford. 1979. Microtetrameres nestoris n. sp. (Nematoda: Spirurida), a parasite of the North Island kaka, Nestor meridionalis septentrionalis (Aves: Psittaciformes). New Zeal J Zool 6, 1-5.

Courtney CH, DJ Forrester. 1974. Helminth parasites of the brown pelican in Florida and Louisiana. Proc Helminthol Soc Wash 41, 89-93.

Chabaud AG, 1975. Keys to genera of the order Spirurida. In: Anderson $\mathrm{R}$, Chabaud AG, Wilmott $\mathrm{S}$ (eds). CIH keys to the nematode parasites of vertebrates. Commonwealth Agricultural Bureaux, Famham Royal, UK, Pp 29-58.

González-Acuña D, O Skewes-Ramm, L Rubilar-Contreras, A Daugschies, K Pohlmeyer. 2000. Endoparásitos de codorniz (Callipepla californica) en Ñuble (Chile). Bol Chil Ornitol 7, 23-25.

González-Acuña D, G Castillo, J López, L Moreno, S Donoso, O Skewes, R Martínez, J Cabello. 2004. Parásitos gastrointestinales y externos de la paloma doméstica (Columba livia) en la ciudad de Chillán, Chile. Agro Ciencia 20, 107-112.

González-Acuña D, M Fabry, AA Nascimento, JH Tebaldi. 2007. Death of two slender-billed parakeets (King) (Enicognathus leptorhynchus) (Aves, Psittacidae) by Ascaridia hermafrodita (Froelich, 1789, Railliet \& Henry, 1914) at the National Zoo of Santiago, Chile. Arq Bras Med Vet Zootec 59, 539-540.

Greiner EC, BW Ritchie. 1999. Parasites. In: Ritchie B, Harrison L, Harrison G (eds). Avian medicine: principles and application. Florida, USA, Pp 862-940.
Hartwich G, W Tscherner. 1979. Ascaridia platyceri $\mathrm{n}$ sp. a new species of nematode from parrots. Angew Parasitol 20, 63-67.

Hinojosa SA, D González-Acuña, 2005. Current state of knowledgments of helmints in Chilean wild birds. Gayana 69, 241-253.

Kajerova V, V Barus, I Literak. 2004a. Nematodes from the genus Ascaridia parasitizing psittaciform birds: a review and determination key. Vet Med Czech 49, 217-223.

Kajerova V, V Barus, I Literak 2004 ${ }^{\text {b }}$. New records of Ascaridia platyceri (Nematoda) in parrots (Psittaciformes). Vet Med Czech 7, 237-241.

Levine BS. 2003. Common disorders of Amazons, Australian parakeets and African grey parrots. Semin Avian Exot Pet 12, 125-130.

Matos R, JK Morrisey. 2005. Emergency and critical care of small psittacines and passerines. Semin Avian Exot Pet 14, 90-105.

Meléndez D, WD Lindquis 1979. Experimental life cycle of Ascaridia columbae in intravenously infected pigeons, Columba livia. $J$ Parasitol 65, 87-88.

Mines JJ. 1979. Ascaridia sprenti, a new species of nematode in Australian parrots. Int J Parasitol 9, 371-379.

Mines JJ, PE Green. 1983. Experimental Ascaridia columbae infections in budgerigars. Aust Vet J 60, 279-280.

Neveu-Lemaire M. 1938. Traité d'entomologie médicale et vétérinaire. Vigot Frères, Paris, France.

Nixton AJ, PJ Weeks. 1985. Parasitism of Chatham island parakeets (Cyanoramphus spp.) by the nematode Ascaridia platyceri. $J R$ Soc N Z 1, 123-125.

Pinto RM, JJ Vicente, D Noronha. 1993. Nematode parasites of Brazilian psittacid birds, with emphasis on the genus Pelecitus Railliet \& Henry, 1910. Mem Inst Oswaldo Cruz 88, 279-284.

Reece RL, PC Scott, DA Barr. 1992. Some unusual diseases in the birds of Victoria, Australia. Vet Rec 130, 178-185.

Schock RC, R Cooper. 1978. Internal parasitisms in captive birds. Mod Vet Pract 59, 439-443.

Serra-Freire NM, I Bianchin. 1978. Sobre quatro especies de Ascaridia (Dujardin, 1845) parasitas de psitacideos, com citação de un novo hospedeiro para A. hermafrodita (Froelich, 1789) (Nematoda: Ascaridoidea) no Brazil. Atas Soc Biol Río de Janeiro 19, 51-54.

Silva RJ, TCG Oliveira-Sequeira, CC Gurgel. 2005. Occurrence of Tetrameres confusa (Nematoda, Tetrameridae) in Ara ararauna (Psittacidae). Arq Bras Med Vet Zootec 57, 562-564.

Sood ML, R Kalia. 1975. Records of two nematode parasites uncommon in birds. Acta Parasitol Polonica 23, 361-365.

Toro H, C Saucedo, C Borie, R Gouch, H Alcaino. 1999. Health status of free-living pigeons in the city of Santiago. Avian Pathol 28, 619-623.

Van den Brand J, R Manvell, P Guntram, MJ Kik, GM Dorrestein. 2007. Reovirus infections associated with high mortality in psittaciformes in The Netherlands. Avian Pathol 36, 293-299.

Webster WA, G Speckmann. 1977. The description of a gubernaculum in Ascarops strongylina (Rudolphi, 1819) (Spiruroidea) and a note on the recovery of this nematode from a bird. Canad J Zool 55, 310-313.

Webster WA. 1982. Internal parasites found in exotic birds imported into Canada. Can Vet J 23, 230.

Weeks PJ. 1981. Ascaridia platyceri in a masked lovebird. New Zeal Vet J 29, 241-242.

Wilson GH, CB Greenacre, EW Howerth, DL Ambrose, D Fontenot. 1999. Ascaridiosis in a group of psittacine birds. J Avian Med Surg 13, 32-39.

Zhang L, DR Brooks, D Causey. 2004. Two species of Synhimantus (Dispharynx) Ralliet, Henry and Sisoff, 1912 (Nematoda: Acuarioidea: Acuariidae), in passerine birds from the Area de Conservation Guanacaste, Costa Rica. J Parasitol 90, 1133-1138. 